\title{
A nonselective cation channel in adult alveolar epithelial cells
}

\author{
BEVERLEY A ORSER MD FRCPC, JEFFREY D EDELSON MD FRCPC \\ Department of Anaesthesia, Sunnybrook Health Science Centre, Department of Physiology, \\ University of Toronto, Department of Medicine, St Michael's Hospital, Toronto, Ontario
}

\section{BA ORSER, JD EDELSON. A nonselective cation channel in adult alveolar epithelial cells. Can Respir J 1994;1(2):129-136.}

OBJECTIVE: Efficient gas exchange across the alveolar membrane requires a dry air space. At birth, active $\mathrm{Na}^{+}$ transport provides the major driving force for absorption of fetal lung liquid, and during adult life, similar transport mechanisms balance fluid exchange across the alveolarcapillary membrane. A cation channel, previously identified in fetal alveolar epithelium, may represent one of several pathways which regulate apical-basal transepithelial $\mathrm{Na}^{+}$ flux. The purpose of this study was to determine if cation channels are also present in adult alveolar epithelial cells.

DESIGN: Standard inside-out patch-clamp recording techniques were used to study channels present in patches of membrane from adult rat alveolar epithelium.

POPUlATION: Alveolar epithelial cells were obtained from adult male Sprague-Dawley rats and studied in primary cell culture.

MAIN ReSUlTS: A 23 pS nonselective cation channel was identified in $68 \%$ of patches voltage clamped to $-60 \mathrm{mV}$. The probability of channel opening was not influenced by changes in membrane potential. Amiloride $\left(10^{-5} \mathrm{M}\right)$ applied to the extracellular membrane induced channel flickering and reduced the apparent mean channel open time without affecting channel conductance.

Conclusions: These results provide direct evidence for a cation channel in the apical membrane of adult alveolar epithelial cells. The channel is similar to a nonselective cation channel in fetal alveolar epithelial cells and may play an important role in $\mathrm{Na}^{+}$-coupled fluid absorption and/or $\mathrm{K}^{+}$ secretion.

Key Words: Alveolar type II epithelium, Ion channel, Lung water. Nonselective cation, Patch-clamp

\section{Un canal cationique non sélectif dans les cellules épithéliales alvéolaires de l'adulte}

OBJECTIF : Pour être efficace, les échanges gazeux à travers la membrane alvéolaire exigent un espace aérien sec. À la naissance, le transport actif du $\mathrm{Na}^{+}$fournit la force motrice pour l'absorption du liquide pulmonaire foetal. À l'âge adulte, des mécanismes de transport similaires régulent les échanges liquidiens à travers la membrane alvéolo-capillaire. Un canal cationique détecté antérieurement dans l'épithélium alvéolaire foetal pourrait représenter l'une des différentes voies de conduction qui régule le flux apico-basal transépithélial du sodium. L'objet de cette étude était de déterminer si des canaux cationiques étaient aussi présents dans les cellules épithéliales alvéolaires de l'adulte.

MoDÈLE: Utilisation de la technique du patch-clamp exposant la face cytoplasmique des canaux pour étudier les canaux présents dans les fragments membranaires de l'épithélium alvéolaire du rat adulte.

Population: Des cellules épithéliales alvéolaires ont été prélevées chez des rats Sprague-Dawley, mâles, adultes, et étudiées par culture cellulaire primaire.

Principaux Résultats : On a identifié un canal cationique 23 pS non sélectif dans $68 \%$ des fragments au potentiel imposé de $-60 \mathrm{mV}$. La probabilité de l'ouverture d'un canal n'a pas été influencée par les variations de potentiel transmembranaire. De l'amiloride $\left(10^{-5} \mathrm{M}\right)$ appliqué sur la membrane extracellulaire a induit une stimulation du canal et a réduit le temps moyen apparent de l'ouverture du canal sans en affecter la conductance.

Conclusions : Ces résultats fournssent la preuve directe de l'existence d'un canal cationique dans la membrane apicale des cellules épithéliales alvéolaires de l'adulte. Le canal est identique à un canal cationique non sélectif identifié dans les cellules épithéliales alvéolaires foetales et peut jouer un role important dans la réabsorption liquidienne couplée au $\mathrm{Na}^{+}$ et/ou dans la sécrétion du $\mathrm{K}^{+}$. 
A

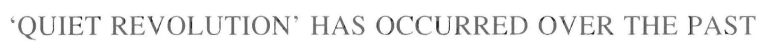
10 years in our understanding of the forces that regulate fluid movement across the alveolar-capillary membrane (1-3). While fluid balance has traditionally been analyzed in terms of hydrostatic and colloid-osmotic pressure gradients, increasing evidence suggests that active ion transport provides the major driving force for absorption of fluid from the alveolar space. The sole importance of 'Starling Forces' was challenged when Matthay et al $(3,4)$ demonstated that proteinaceous fluid instilled into lungs of sheep, was absorbed despite the presence of a large opposing osmotic pressure gradient. The relative contribution of passive and active forces was investigated by Basset et al (5). They determined that human lung depends primarily on active transport mechanisms similar to other fluid absorbing surfaces and estimated that the human lung is capable of absorbing $1.5 \mathrm{~L}$ of fluid over a $24 \mathrm{~h}$ period (5).

The mechanisms that regulate solute-coupled fluid transport in the lung are of considerable clinical importance. Several diseases, including respiratory distress syndrome (RDS) in the newborn and pulmonary edema in the mature lung, result from a fluid imbalance across the alveolarcapillary membrane. O'Brodovich et al (6) reported that an 'RDS-like syndrome' was induced in full-term, newborn guinea-pigs when the $\mathrm{Na}^{+}$transport inhibitor amiloride was instilled into the lungs before the first breath. This observation raises the possibility that defects in ion transport, as well as surfactant deficiency, contribute to disease in the premature lung. In adult humans, survival from acute lung injury correlates with the restoration of normal ion transport, suggesting that solute-coupled transport is essential for recovery from alveolar flooding (7).

Determining which cells are responsible for lung fluid clearance has been complicated by the complex anatomy of the lung. Cell culture techniques that allow select populations of cells to be studied in vitro have provided insights into the transport capabilities of the alveolar epithelium. Isolated type II alveolar epithelial cells, grown on porous supports, spread to form confluent monolayers $(8,9)$. Osmotic forces generated by the active transport of ions from the apical to basolateral membrane cause fluid to accumulate beneath these cells. The resulting dome-like structures are characteristic of fluid absorbing epithelia and result from $\mathrm{Na}^{+}$-coupled transport. The bioelectric properties of alveolar epithelial cells have also been studied in Ussing chambers. Fetal and adult alveolar epithelial cells form 'tight', high resistance membranes and generate an amiloride-sensitive, $\mathrm{Na}^{+}$-dependent, shortcurcuit current (9-11). These data indicate that alveolar epithelial cells have the bioelectric characteristics necessary for active ion transport (12).

The rate of solute translocation across the alveolar epithelium suggests that the apical site for $\mathrm{Na}^{+}$entry is an ion channel rather than a cotransport system $(13,14) .{ }^{22} \mathrm{Na}^{+}$flux measurements from membrane vesicles prepared from adult alveolar epithelium and whole-cell patch-clamp recordings support the presence of amiloride-sensitive $\mathrm{Na}^{+}$channels $(13,14)$. Recently, an amiloride-sensitive channel which was
TABLE 1

Concentrations ( $\mathrm{mM}$ ) used in solutions $A$ to $D$

\begin{tabular}{lcccc}
\hline & \multicolumn{4}{c}{ Solution } \\
& A & B & C & D \\
\hline Sodium chloride & 140 & 0 & 47 & 140 \\
Potassium chloride & 0 & 140 & 0 & 0 \\
Calcium chloride & 1.5 & 1.5 & 1.5 & 1.5 \\
Sucrose & 0 & 0 & 187 & 0 \\
Glucose & 10 & 10 & 10 & 10 \\
HEPES & 10 & 10 & 10 & 10 \\
pH & 7.4 & 7.4 & 7.4 & 7.4 \\
Amiloride & 0 & 0 & 0 & $10^{-5} \mathrm{M}$ \\
\hline
\end{tabular}

permeable to $\mathrm{Na}^{+}$and $\mathrm{K}^{+}$was identified in fetal alveolar epithelium $(15,16)$. To examine the possibility that fetal and adult alveolar cells use similar apical $\mathrm{Na}^{+}$transport pathways, we attempted to determine if this channel is also present in adult alveolar epithelial cells. Part of this work was previously published in abstract form (17).

\section{METHODS \\ Primary culture of adult epithelial cells}

Alveolar epithelial cells were obtained from the lungs of adult male Sprague-Dawley rats using the method of Dobbs et al (18). In brief, alveolar cells were separated from the basement membrane by incubation with porcine pancreatic elastase followed by removal of macrophages by differential adherence. Cells were seeded at a plating density of $5 \times 10^{5}$ cells $/ \mathrm{cm}^{2}$ on collagen coated plastic petri dishes and cultured in a humidified incubator (95\% air, 5\% carbon dioxide) at $37^{\circ} \mathrm{C}$ for 24 to $48 \mathrm{~h}$. Alveolar epithelial cells grown under these culture conditions develop the morphological characteristics of polarized epithelia $(10,19)$. It was therefore assumed that a patch excised from the surface of these cells was obtained from the apical membrane. The purity of alveolar epithelial cell cultures was measured by histochemical staining for alkaline phosphatase (20) and was consistently greater than $93 \%$.

\section{Single channel recording and analysis techniques}

The composition of solutions used in the experiments is indicated in Table 1. All solutions contained $1.5 \mathrm{mM} \mathrm{Ca}^{2+}$ as it was previously observed that the stability of the patch improved when high concentrations of $\mathrm{Ca}^{2+}$ were present in the recording media (15). All solutions were filtered (0.22 $\mu \mathrm{M})$ (Millipore Products, Massachusetts) before use.

Electrodes were constructed from borosilicate glass (1.5 $\mathrm{mm}$ outer diameter) (World Precision Instruments Inc, Florida) coated with Sylgard (Dow Corning, Michigan) and fire polished (Narishige, Tokyo, Japan). Conventional techniques were used to acquire inside-out membrane patches and all experiments were performed at room temperature. Cells were visualized using an inverted microscope (Zeiss, Germany) and currents were recorded using an Axo-patch amplifier (Axon Instruments, California). 
The connection of the perfusion chamber to the ground was established using a silver-silver chloride pellet electrode, whereas the pipette was coupled to the headstage using a silver-silver chloride wire. At the beginning of each experiment, the recording pipette was immersed in a solution containing $140 \mathrm{mM}$ sodium chloride (solution A) and the amplifier potential was set to zero. It was assumed that no junctional potentials developed when the bath solution was exchanged with a solution containing $140 \mathrm{mM}$ potassium chloride (solution B). However, when the bathing solution was replaced with one containing $47 \mathrm{mM}$ sodium chloride (solution C), important junctional potentials were expected to occur. These potentials could influence the accuracy of the measured zero current potentials and hence the calculation of relative permeability of the channel to anions and cations.

We measured the value of the junctional potentials $\left(\mathrm{V}_{\mathrm{LJ}}\right)$ using membrane-free electrodes filled with the standard pipette solution (21). The pipette was immersed in the bathing solution (solution A) and the amplifier zeroed. The bathing solution was then exchanged with solution $\mathrm{C}$ and the amplifier potential was set to zero several times over the next 5 mins. The amplitude of the compensating potential was noted. When the variation in the compensating voltage was less than $1 \mathrm{mV}$ over 2 to 3 mins, the signal was considered to be stable. Junctional potentials were measured for seven electrodes and the mean $V_{\mathrm{LJ}}$ was added to the measured zero current potential ( $V_{\text {Measured }}$ ) in order to obtain the reversal potential ( $\left.\mathrm{V}_{\mathrm{Rev}}\right)$

$$
V_{\text {Rev }}=V_{L J}+V_{\text {Measured }}
$$

The permeability of the channel for $\mathrm{Cl}^{-}$anions was expressed as the $\mathrm{Cl}^{-}$permeability to $\mathrm{Na}^{+}$permeability ratio $\left(\mathrm{PCl}_{\mathrm{Cl}} / \mathrm{P}_{\mathrm{Na}}\right)$ and was analyzed using the Goldman-Hogkin-Katz (GHK) equation for the reversal potential. Activities rather than concentrations were used for all calculations of ion permeability.

Current signals were filtered at $1 \mathrm{kHz}$ and recorded onto an FM tape. For analysis, data records were played back off the tape, sampled at 100 to $200 \mu$ s and stored on a personal computer. Records were analyzed using pCLAMP program (Axon Instruments) and single-channel events were detected using the $50 \%$ threshold crossing method. Dwell times were reported as the arithmetic mean of channel open times. Single channel conductance was determined using amplitude histograms and the slope of the current to voltage (i-v) curve. Membrane potential refers to the intracellular or cytoplasmic potential relative to extracellular or pipette potential, which is assumed to be zero. Inward currents are depicted as downward deflections in all current tracings. The probability of channel opening $\left(\mathrm{P}_{\text {open }}\right)$ was determined as previously reported using the relative areas of the all-points histograms (15). A one-way analysis of variance (ANOVA) was used to examine differences in open channel probability at the various holding potentials. A Student's $t$ test (unpaired) was used to analyze differences in open dwell times between control and amiloride treated patches. $\mathrm{P}<0.05$ was considered statis-

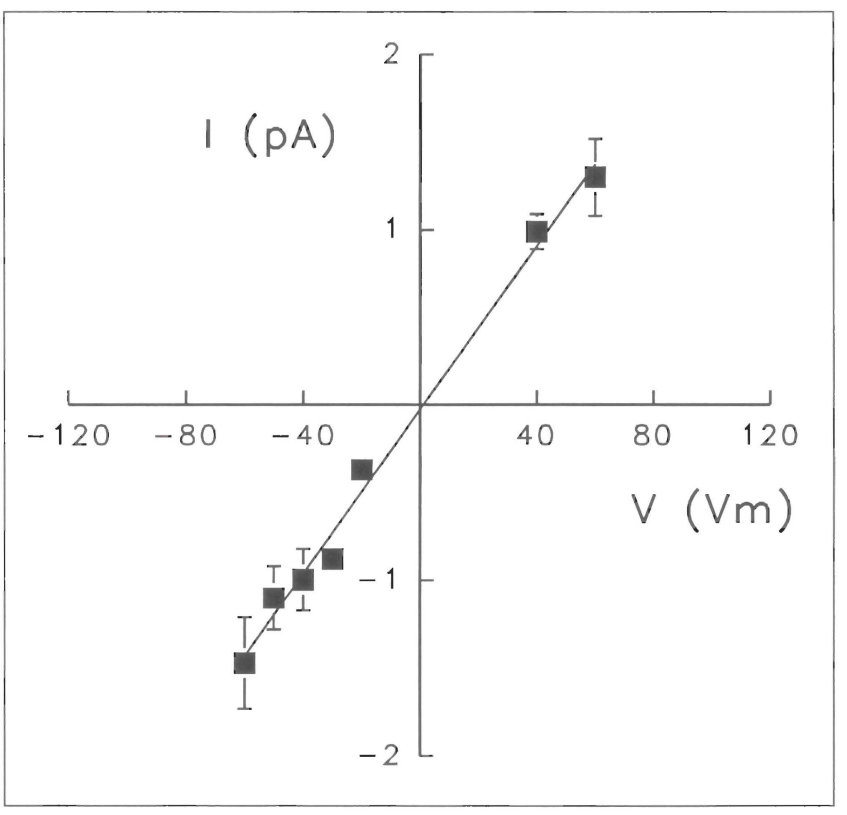

Figure 1) The current-voltage ( $i$-v) relation of a cation channel excised from the apical surface of adult alveolar type II epithelial cells. The solution in the bath and recording electrode contained $140 \mathrm{mM}$ sodium chloride (solution A). Data points represent the mean current recorded from seven patches. The vertical error bars indicate the standard deviation for currents recorded from three or more patches. The relationship is linear with a slope conductance of $23.3 \pm 1.5 \mathrm{pS}$

tically significant. All results are reported as mean \pm one standard error unless stated otherwise.

\section{RESULTS}

Adult alveolar epithelial cells grown on a collagen matrix adopted a typical 'cobblestone' appearance when examined using inverted light microscopy. Patches were excised from cells located in the centre of the clusters. High resistance seals (giga- $\Omega$ ) were difficult to form on the surface of the cells and excised patches frequently became unstable during exchanges of the bathing solution or following membrane depolarization. In contrast to alveolar epithelium, the present authors have studied other cell types including cultured neurons and transfected epithelia without difficulty using the same techniques and recording equipment.

With symmetrical concentrations of sodium chloride (140 $\mathrm{mM}$, solution $\mathrm{A}$ ) in the pipette and bath and the membrane voltage clamped to $0 \mathrm{mV}$, no current events were observed. Membrane hyperpolarization evoked inward current events and membrane depolarization induced outward current, respectively. Channel openings were observed in 68\% (24 of 35 ) of patches voltage clamped to $-60 \mathrm{mV}$. In most recordings, a single conductance state was evident suggesting the presence of a single channel. In $21 \%$ of active patches, two or more conductance levels of equal amplitude were observed. The relationship between current (i) and voltage (v) was plotted and the slope of the line of linear regression used to estimate channel conductance. The $\mathrm{i}-\mathrm{v}$ curve was linear with a reversal potential close to $0 \mathrm{mV}$ (Figure 1). The 


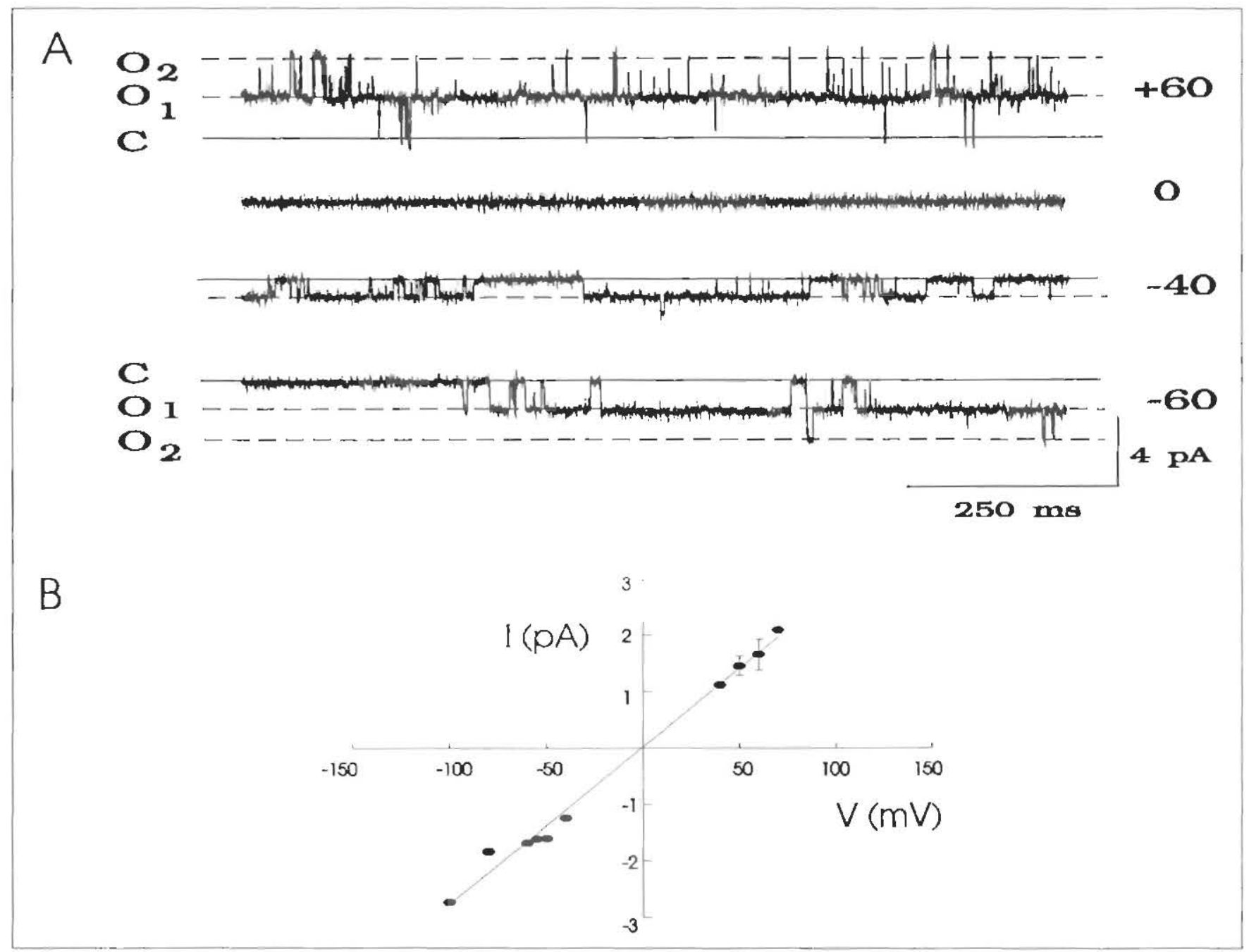

Figure 2) Selectivity of the cation channel in alveolar epithelial cells. A Single channel currents recorded with sodium chloride (140 mM) in the pipette and potassium chloride $(140 \mathrm{mM})$ in the bathing solution. The closed (c) and open (o) states are denoted by the solid and dashed lines. respectively. Intracellular holding potentials are shown to the right of the current tracings. Two open levels were observed, indicating the presence of at leasi wo channels in the membrane patch. B The current-voltage $(i-v)$ relation for currents recorded with $140 \mathrm{mM}$ potassium chloride in the bathing solution ( $n=5$ patches). The slight shift of the zero current potential $(-2.6 \mathrm{~m} V$ ) under these assmmetrical recording ronditions indicates that the chamnel is highly permeant $10 \mathrm{~K}^{+}$and $\mathrm{Na}^{+}$

estimated single channel conduclance was $23.3 \pm 1.5 \mathrm{pS}(n=7)$.

In order to exanime the selectivity of the channel for cations, the bath was cxchanged with a solution containing polassium chloride $140 \mathrm{mM}$ (solution B). Channel openings were not evident whell the uncinbrane was voltage clamped to $0 \mathrm{mV}$. However, currents with amplitudes similar to those accorded with sodium chloride $(140 \mathrm{mM})$ solution in the bath and clecurode were observed following membrane hyperpolarizalion and depolarization (Figure 2). Under these conditions. Ile plos of the $\mathrm{i}-\mathrm{v}$ relation had linear slope (unductance of $25.8 \pm 2.5 \mathrm{pS}(n=5)$ and a reversal potential (likev) of $-2.6 \pm 2.0 \mathrm{mV}$. The relative permeability of the channel to $\mathrm{Na}^{+}$and $\mathrm{K}^{+}$, calculated using the GHK equalion. was $\mathrm{PNa}^{+} / \mathrm{PK}^{+}=0.88$. These results indicate that the chammel was highly permeable to $\mathrm{Na}^{+}$and $\mathrm{K}^{+}$.

The relative cation and anion selectivity of the channel Was cxamined by exchanging the bath with an isotonic solu tion containing a low concentration ol sodium chloride. With the pipetle containing sodium chloride (140 $\mathrm{mM}$. solution $\mathrm{A})$ and the bath containing sodium chloride ( $47 \mathrm{mM}$, solution ('). inward current was observed when the membrane potential was held at $0 \mathrm{mV}$ (Figure 3). The amplitude of the inward currents recorded during membrane hyperpolarization was increased relative to the amplitude of events measured with symmetrical concentrations of sodium chloride in the bath and pipette. The $\mathrm{i}-\mathrm{v}$ relation was shifted to the right and the zero current potential was $+22.3 \pm 4.3 \mathrm{mV}(n=3)$ The value of the $V_{L}$ measured under these recording conditions was $+8.1 \pm 1.2 \mathrm{mV}\left(n=7\right.$ electrodes). The calculated $V_{\text {Rev }}$ was. therefore, $+30.4 \mathrm{mV}$. This value was close to that predicted from the GHK voltage equation $(+27 \mathrm{mV})$ for a channel impermeable to chloride ions. The permeability ratio ( $\mathrm{PCl}^{-}$) $\mathrm{PNa}^{+}$) was 0.038 , demonstrating that the channel is relalively impermeable to $\mathrm{Cl}^{-}$anions

The dashed curve in rigure 3 indicates lia i-v relation predicted by the GltK current equation for a channel com- 


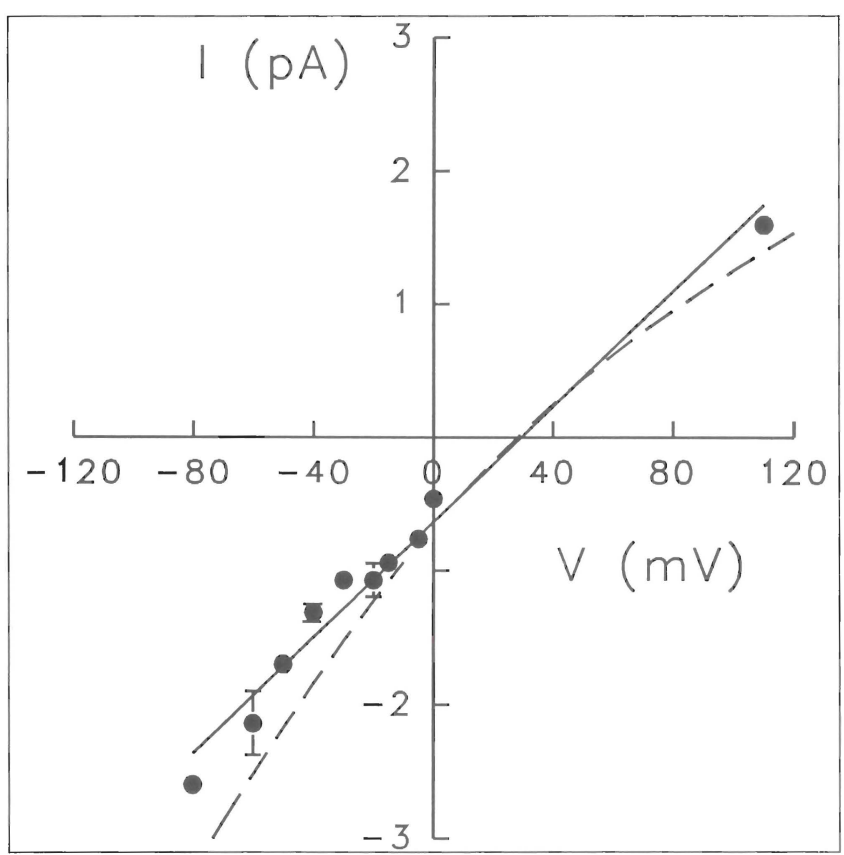

Figure 3) Anion selectivity of the channel. The current-voltage ( $i$-v) relationship for three patches recorded with $47 \mathrm{mM}$ sodium chloride in the bath and $140 \mathrm{mM}$ sodium chloride in the pipette. The solid line indicates the line of linear regression through the data points. Under these recording conditions the $i$-v curve is shifted to the right with an $\mathrm{x}$ intercept of $22 \pm 3 \mathrm{mV}$. The dashed line represents the $i-v$ curve predicted from the GHK constant field equation for a channel completely selective for cations where:

$i=E F / R T * \mathrm{PNa}^{+} *\left[\mathrm{Na}^{+}\right] \mathrm{e}-\left[\mathrm{Na}{ }^{+}\right] i \exp (\mathrm{EF} / \mathrm{RT}) / \mathrm{I}-\exp (\mathrm{EF} / \mathrm{RT})$

$E$ is the membrane potential, $\mathrm{Na}^{+} i$ and $\mathrm{Na}^{+} e$ are $47 \mathrm{mM}$ and 140 $m M$, respectively. PNa was estimated to be $7.210^{-14} \mathrm{~cm}^{3} / \mathrm{s}$

pletely selective for cations. There are several possible reasons why these data deviated slightly from the theoretical curve. The GHK current equation, similar to the GHK voltage equation, depends on two important assumptions: ions move independently through the channel pore and the electrical field in the membrane is constant with membrane potential decreasing linearly across the cell membrane (22). In reality, biological membranes are not homogeneous slabs, and ion fluxes are not linearly proportional to ion concentrations. Interactions between ions and energy barriers within the channel pore may have reduced the movement of ions across the membrane.

Voltage sensitivity of channel gating was investigated by examining the relationship between membrane potential and the probability of channel opening $\left(\mathrm{P}_{\text {open }}\right)$. The probability of channel opening was not significantly influenced by changes in membrane potential (Figure 4). For example, at a holding potential of $-40 \mathrm{mV}$, the probability of channel opening was $0.39 \pm 0.07(n=4)$ whereas $P_{\text {open }}$ was $0.34 \pm 0.12(n=4)$ when the membrane was depolarized to $+40 \mathrm{mV}$.

The addition of amiloride $\left(10^{-5} \mathrm{M}\right)$ to the pipette solution (solution D) consistently altered channel openings from long rectangular events to brief flickering events (Figure 5). The duration of channel opening was significantly reduced in amiloride versus control patches when measured at a mem-

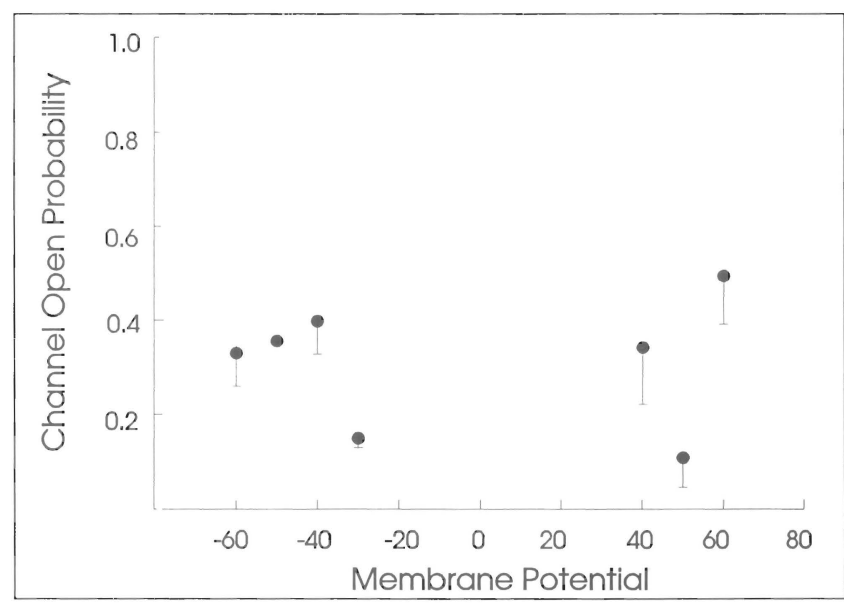

Figure 4) Effect of membrane potential on the probability of channel opening. Currents were recorded with sodium chloride (140 $m M)$ in the bath and recording electrode. No significant difference was observed for open probability of the channel when measured at hyperpolarizing and depolarizing membrane potentials $(n=4)$

brane potential of $-60 \mathrm{mV}$. In control records, mean open time was $22.07 \pm 4.9 \mathrm{~ms}(\mathrm{n}=4)$. Amiloride treated channels had a mean open time of $5.1 \pm 1.6 \mathrm{~ms}(\mathrm{n}=4)(\mathrm{P}<0.05)$. Single channel conductance was not influenced by amiloride $\left(10^{-5} \mathrm{M}\right)(\mathrm{P}>0.05):$

$$
\begin{aligned}
& \text { gcontrol }=24.5 \pm 1.8 p S(n=4) \\
& \text { gamiloride }=27.8 \pm 1.9 p S(n=4)
\end{aligned}
$$

\section{DISCUSSION}

The patch-clamp method has recently provided significant insights into the role ion channels play in respiratory disease (23-26). Despite the importance of the alveolar membrane for normal lung function, studies of channels present in alveolar epithelial cells have been limited. This is due, in part, to difficulties experienced by ourselves and others in obtaining high quality recording conditions with primary epithelial cells grown in dissociated cell cultures (27). This report describes a $23 \mathrm{pS}$ nonselective cation channel present in the apical membrane of adult alveolar epithelial cells. The channel was permeable to $\mathrm{Na}^{+}$and $\mathrm{K}^{+}$but relatively impermeable to anions. The probability of channel opening was insensitive to changes in membrane potential and amiloride-induced channel flickering and reduced channel open time.

The single channel characteristics of the nonselective cation channel present in fetal and adult alveolar epithelial cells are remarkably similar. The 23 to $25 \mathrm{pS}$ fetal channel is also voltage-insensitive, selective for $\mathrm{K}^{+}$, impermeable to $\mathrm{Cl}^{-}$and blocked by amiloride $(3,4)$. In contrast, in our findings, the selectivity and kinetic properties of several other channels studied in fetal and adult cells change dramatically during the first few weeks of postnatal life (28-30). For example, the acetylcholine receptor/ionophore is a nonselective cation 
A

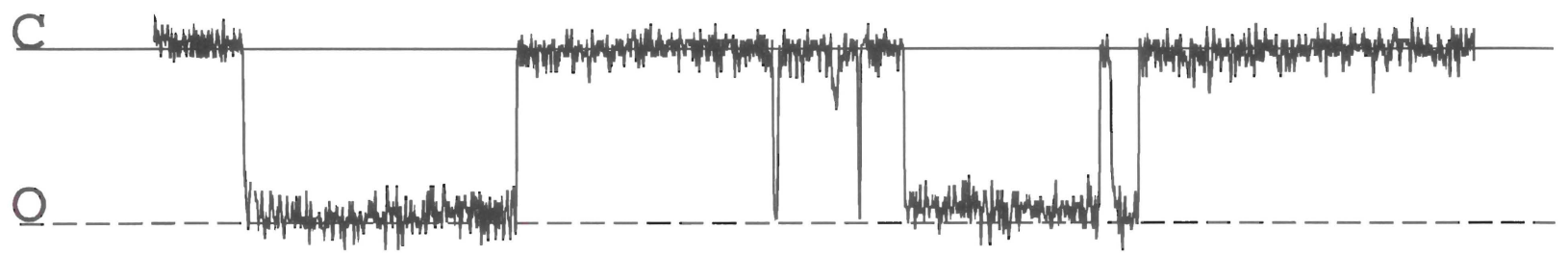

B

AMILORIDE

$\left(10^{-5}\right.$

M)

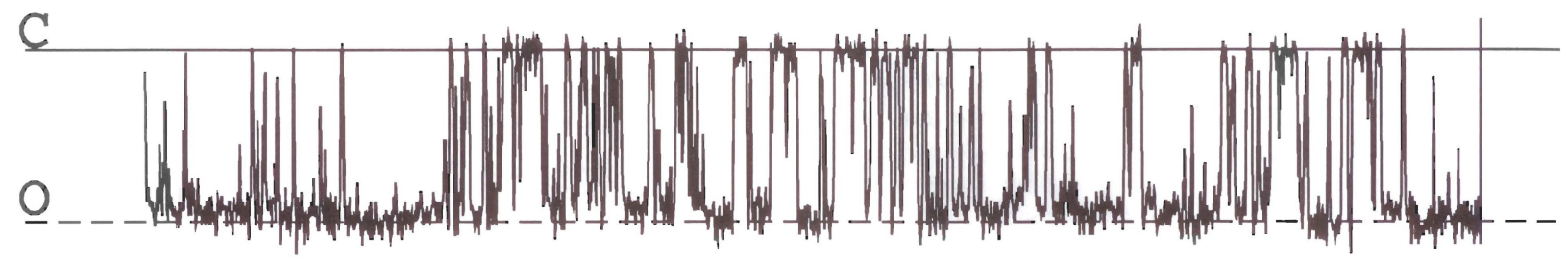

1 PA

\section{$100 \mathrm{~ms}$}

Figure 5) Amiloride-sensitivity of the nonselective cation channel. Single-channel currents recorded from two inside-out patches voltage clamped to $-60 \mathrm{mV}$. A Channel openings from a patch recorded with sodium chloride $(140 \mathrm{mM})$ in the bath and pipette. $\mathbf{B}$ When amiloride $10^{-5} \mathrm{M}$ (solution D) was added to the pipette solution, channel flickering was consistently observed. Both current records were filtered at $1 \mathrm{kHz}$ and sampled at $100 \mu \mathrm{s} /$ point

channel present in the neuromuscular junction. During early postnatal development, channel conductance increases by approximately $50 \%$ whereas the average duration of channel opening is reduced. These changes result from a substitution in one of the protein constituents that form the acetylcholine channel pore (31). Our results indicate that the nonselective cation channel in fetal alveolar epithelial cells does not undergo dramatic postnatal modifications. In addition, channel behaviour did not appear to be influenced by the different enzymes and procedures used to dissociate fetal and adult alveolar epithelia.

\section{Physiological role of a nonselective cation channel}

According to the Koefoed-Johnsen-Ussing model of ion transport, epithelial cells maintain a low intracellular concentrations of $\mathrm{Na}^{+}$and high intracellular concentrations of $\mathrm{K}^{+}$by actively exchanging ions across the basolateral cell mem- brane (14). The enzyme $\mathrm{Na}^{+}, \mathrm{K}^{+}$-ATPase ensures the maintenance of a favourable electrochemical gradient for $\mathrm{Na}^{+}$influx, and $\mathrm{Na}^{+}$enters the cell by diffusing through channels or by coupling to transport proteins located in the apical membrane. The net transport of $\mathrm{Na}^{+}$from the apical to basolateral membrane generates the osmotic force that drives fluid movement across the epithelial barrier. The rate of transeptthelial $\mathrm{Na}^{+}$flux, and hence fluid absorption, is primarily governed by the ion channels present in the apical membrane. The nonselective cation channel we described could be the apical $\mathrm{Na}^{+}$pathway and would therefore regulate $\mathrm{Na}^{+}$-coupled fluid absorption.

Our results also demonstrated that the channel was highly permeable to $\mathrm{K}+$. Under normal physiological conditions, channel opening would allow $\mathrm{K}+$ efflux into the alveolar space. Such a mechanism is supported by the high concentration of $\mathrm{K}^{+}$in the alveolar subphase. In humans and animals, the concentration of $\mathrm{K}^{+}$in the fluid lining the alveolus is 
approximately twice the concentration of $\mathrm{K}^{+}$in the plasma $(32,33)$. Channels that are highly selective for $\mathrm{K}^{+}$and $\mathrm{K}^{+}$ -dependent cotransport systems are also present in the apical membrane of alveolar epithelial cells and may also contribute to $\mathrm{K}^{+}$secretion (34-37).

Nonselective cation channels have been described in several other epithelial and nonepithelial cell types (38-44). Physiological functions attributed to these channels include: electrogenic $\mathrm{Na}^{+}$absorption, stimulus-secretion coupling, excitation-contraction coupling, and control of resting membrane potential. Interestingly, an amiloride-insensitive nonselective cation channel has recently been identified in human nasal epithelium (45). This channel is also present in patients with cystic fibrosis and may contribute to the pathogenesis of the disease (45).

In our preparation, the activity of the nonselective cation channel was examined using the inside-out patch configuration, in the presence of high concentrations of $\mathrm{Ca}^{2+}$. The concentration of $\mathrm{Ca}^{2+}$ in the cytosol may have influenced the single channel characteristics. Recently, Marunaka et al (16) reported for the nonselective channel in fetal alveolar epithelial cells that lowering the concentration of $\mathrm{Ca}^{2+}$ in the bathing solution decreased the probability of channel opening, increased amiloride sensitivity and increased the selectivity of the channel for $\mathrm{Na}^{+}$relative to $\mathrm{K}^{+}$. These findings suggest that, in vivo, the 'nonselective' channel may be a

\section{REFERENCES}

1. Strang LB. Fetal lung liquid: Secretion and reabsorption. Physiol Rev 1991;71:991-1016.

2. Saumon G, Basset G. Electrolyte and fluid transport across the mature alveolar epithelium. J Appl Physiol 1993;74:1-15.

3. Matthay MA, Landolt CC, Staub NC. Differential liquid and protein clearance from the alveoli of anesthetized sheep. J Appl Physiol 1982;53:96-104.

4. Berthiaume Y, Broaddus VC, Gropper MA, Tanita T, Matthay MA. Alveolar liquid and protein clearance from normal dog lungs. J Appl Physiol 1988;65:585-93.

5. Basset G, Crone C, Saumon G. Significance of active ion transport in transalveolar water absorption: A study on isolated rat lung. J Physiol 1987;384:311-24.

6. O’Brodovich H, Hannam HV, Seear M, Mullen JBM. Amiloride impairs lung water clearance in newborn guinea pigs. J Appl Physiol 1990;68:1758-62.

7. Matthay MA. Wiener-Kronish JP. Intact epithelial barrier function is critical for the resolution of alveolar edema in man. Am Rev Respir Dis 1990;142:1250-7.

8. Goodman BE, Crandall ED. Dome formation in primary cultured monolayers of alveolar epithelial cells. Am J Physiol (Cell Physiol 12) 1982;243:C96-100.

9. O'Brodovich H, Raffi B, Post M. Bioelectric properties of fetal alveolar epithelial monolayers. Am J Physiol (Lung Cell Mol Physiol 2) 1990;258:L201-6.

10. Cheek MJ, Kwang-Jim K, Crandall ED. Tight monolayers of rat alveolar epithelial cells: bioelectric properties and active sodium transport. Am J Physiol (Cell Physiol 25) 1989;256:C688-93.

11. Mason RJ, Williams MC, Widdicombe JH, Sanders MJ. Misfeldt DS, Berry LC Jr. Transepithelial transport by pulmonary alveolar type II cells in primary culture. Proc Natl Acad Sci USA 1982;79:6033-7.

12. Koefoed-Johnsen V, Ussing HH. The nature of the frog skin potential. Acta Physiol Scand 1958:42:298-308. selective $\mathrm{Na}^{+}$conduit. The authors also reported that the beta-adrenergic agonist terbutaline increased the probability of channel opening. This observation is important because adrenergic stimulation accelerates the clearance of fluid from the air spaces and stimulates active ion transport in alveolar epithelium (1,46-49). Further studies are required to determine whether channel activity is modulated by other factors that influence alveolar fluid absorption.

In summary, the $23 \mathrm{pS}$ nonselective channel identified in adult alveolar epithelial cells is similar to a cation channel present in fetal alveolar cells. This channel may participate in absorption of alveolar fluid, and we speculate that impaired channel function contributes to the reduction of fluid clearance observed in acute lung injury. Our data provide the basis for further investigation of channel activity under various physiological and pathological conditions.

ACKNOWLEDGEMENTS: Dr Orser was previously a Fellow of the Parker B Francis Foundation and is currently a Fellow of the Medical Research Council of Canada. We thank Mr J Plumb for technical assistance and Dr D Marcus for the curve fitting program. Since submission of this manuscript, similar results were published by Z-P Feng, RB Clark and Y Berthiaume (Am J Respir Cell Mol Biol 1993;9:248-54), also demonstrating the presence of an amiloride-sensitive nonselective cation channel in adult alveolar type II cells.

13. Matalon S, Bridges RJ, Benos DJ. Amiloride-inhibitable $\mathrm{Na}^{+}$ conductive pathways in alveolar type II pneumocytes. Am J Physiol (Lung Cell Mol Physiol 4) 1991;260:L90-6.

14. Bubien J, Benos DJ, Matalon S. Identification of amiloride-inhibitable sodium currents across freshly-isolated alveolar type II pneumocytes. Am Rev Respir Dis 1990;141:A842. (Abst)

15. Orser BA, Bertlik M, Fedorko L, O'Brodovich H. Cation selective channel in fetal alveolar type II epithelium. Biochim Biophys Acta (Mol Cell Res) 1991;1094:19-26.

16. Marunaka Y, Tohda H, Hagiwara N, O’Brodovich H. Cytosolic $\mathrm{Ca}^{2+}$-induced modulation of ion selectivity and amiloride sensitivity of a cation channel and beta agonist action in fetal lung epithelium. Biochim Biophys Acta 1992;187:648-56.

17. Orser BA, Fedorko L, Edelson J, O’Brodovich H. Non-selective cation channel in adult and fetal alveolar epithelium. FASEB J 1991;5:1764. (Abst)

18. Dobbs LG, Gonzalez R, Williams MC. An improved method for isolating type II cells in high yield and purity. Am Rev Respir Dis 1986;134:141-5.

19. Mason JR, Williams MC, Widdicombe JH, Sanders MJ. Misfeldt DA, Berry LC. Transepithelial transport by pulmonary alveolar type II cells in primary culture. Proc Natl Acad Sci 1982;79:6033-7.

20. Edelson DE, Shannon JM, Mason RJ. Alkaline phosphatase: A marker of alveolar type II cell differentiation. Am Rev Respir Dis 1988:138:1268-75.

21. Banderall U, Roy G. Anion channels for amino acids in MDCK cells. Am J Physiol 1992;263:C1200-7.

22. Hille B. Channels in Excitable Membranes, 2nd edn. Sutherland: Sinauer Associates Inc, 1992.

23. Frizzell RA, Rechkemmer G, Schomaker RL. Altered regulation of airway epithelial cell chloride channels in cystic fibrosis. Science 1986;232:1648-50.

24. Kunzelmann K, Pavenstadt H, Greger R. Properties and regulation of chloride channels in cystic fibrosis and normal 
airway call. Pflugers Arch 1989;415:172-82.

25. Welsh MJ. An apical membrane chloride channel in human tracheal epithelium. Science 1986;232:1648-50.

26. Kunzelmann K, Pavenstadt H, Greger R. Characterization of potassium channels in respiratory cells. Inhibitors and regulators. Pflugers Arch 1989;414:297-303.

27. Jorissen M, Vereecke J, Carmeliet E, Van den Berghe H, Cassiman J-J. Non-selective cation and dysfunctional chloride channels in the apical membrane of nasal epithelial cells cultured from cystic fibrosis patients. Biochim Biophys Acta 1991;1096:52-9.

28. Cherubini E, Gaiarsa JL, Yehezkel B-A. GABA: an excitatory transmitter in early postatal life. Trends Neurosci 1991;14:515-9.

29. Vicini S, Schuetze SM. Gating properties of acetylcholine receptors at developing rat endplates. J Neurosci 1985:5:2212-24.

30. Sakmann B, Brenner HR. Change in synaptic channel gating during neuromuscular development. Nature 1978;276:401-2.

31. Mishina M, Takai T, Imoto K, et al. Molecular distinction between fetal and adult forms of muscle acetylcholine receptor. Nature 1986;321:406-11.

32. Nielson DW. Electrolyte composition of pulmonary alveolar subphase in anesthetized rabbits. J Appl Physiol 1986;60:972-8.

33. Valeyre D, Soler P, Basset G, et al. Glucose $\mathrm{K}^{+}$and albumin concentrations in the alveolar milieu of normal humans and pulmonary sarcoidosis patients. Am Rev Respir Dis 1991;143:1096-101.

34. Peers C, Kemp PJ, Boyd CAR, Nye PCG. Whole-cell K currents in type II pneumocytes freshly isolated from rat lung: pharmacological evidence for two subpopulations of cells. Biochim Biophys Acta 1990;1052:113-8.

35. DeCoursey T, Jacobs E, Silver MR. Potassium currents in rat type II alveolar epithelial cells. J Physiol Lond 1988:395:487-505.

36. Orser B, Fedorko L, Rafii B, Post M, O’Brodovich H. Influence of gestational age on potential difference across fetal type II alveolar epithelium in alveolar-like structures. Biol Neonate 1991:59:61-8.

37. Effros RM, Mason GR, Hukkanen J, Silverman P.
Reabsorption of solutes and water from fluid-filled rabbit lungs. Am Rev Respir Dis 1987;66:966-76.

38. Hamilton K, Benos DJ. A non-selective cation channel in the apical membrane of cultured A6 kidney cells. Biochim Biophys Acta 1990;1031:16-23.

39. Sturgess NC, Hales CN, Ashford MLJ. Inhibition of a calcium-activated, non-selective cation channel, in a rat insulinoma cell line, by adenine derivatives. FEBS Lett 1986;208:397-400. (Lett)

40. Yellen G. Single $\mathrm{Ca}^{2+}$-activated nonselective cation channels in neuroblastoma. Nature 1982;296:357-9.

41. Horn R, Patlak J. Single channel currents from excised patches of muscle membrane. Proc Natl Acad Sci USA 1980;77:6930-4.

42. Gogelein H, Pfannmüller F. The nonselective cation channel in the basolateral membrane of rat exocrine pancreas. Pflügers Arch 1989;413:287-98.

43. Light DB, Schwiebert EM, Karlson KH, Stanton BA. Atrial natriuretic peptide inhibits a cation channel in renal inner medullary collecting duct cells. Science 1989;243:383-5.

44. Joris L, Krouse ME, Hagiwara G, Bell CL, Wine JJ. Patch-clamp study of cultured human sweat duct cells: amiloride-blockable $\mathrm{Na}^{+}$channel. Pflügers Arch 1989;414:369-72.

45. Krouse ME, Hagiwara JC, Lewiston NJ, Wine JJ. Ion channels in normal and cystic fibrosis sweat gland cells. Am J Physiol 1989; 257:C129-40.

46. Berthiaume Y, Staub NC, Matthay MA. Beta-adrenergic agonists increase lung liquid clearance in anesthetized sheep. J Clin Invest 1987;79:335-43.

47. Saumon G, Basset G, Bouchonnet F. Crone C. cAMP and B-adrenergic stimulation of rat alveolar epithelium: effects on fluid absorption and paracellular permeability. Pflügers Arch 1987:410:464-70.

48. Cott GR, Sugahara K, Mason RJ. Stimulation of net active ion transport across alveolar type II cell monolayers. Am J Physiol (Cell Physiol 19) 1986;250:C222-7.

49. Berthiaume Y, Broaddus VC, Gropper MA, Tanita T, Matthay MA. Alveolar liquid and protein clearance from normal dog lungs. J Appl Physiol 1988;65:585-93. 


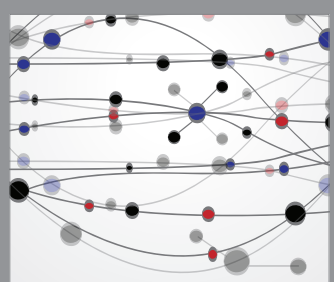

The Scientific World Journal
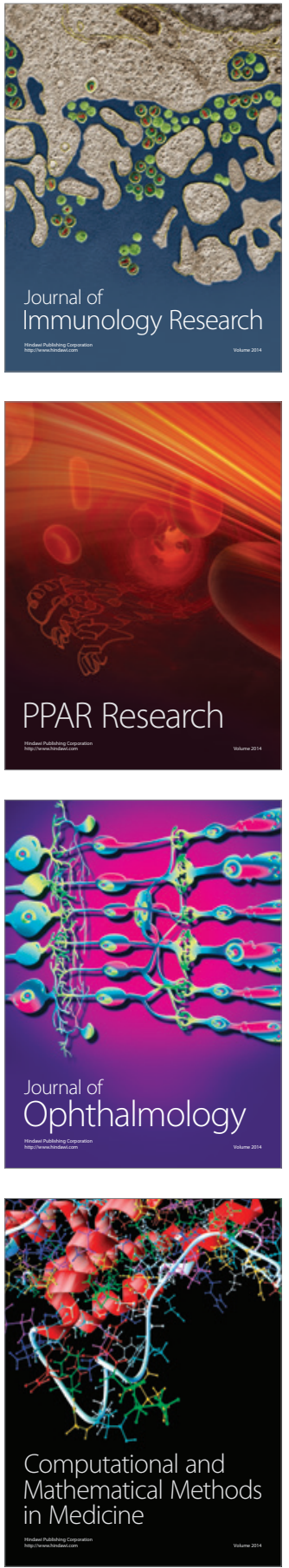

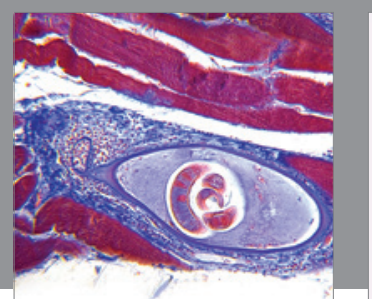

Gastroenterology Research and Practice

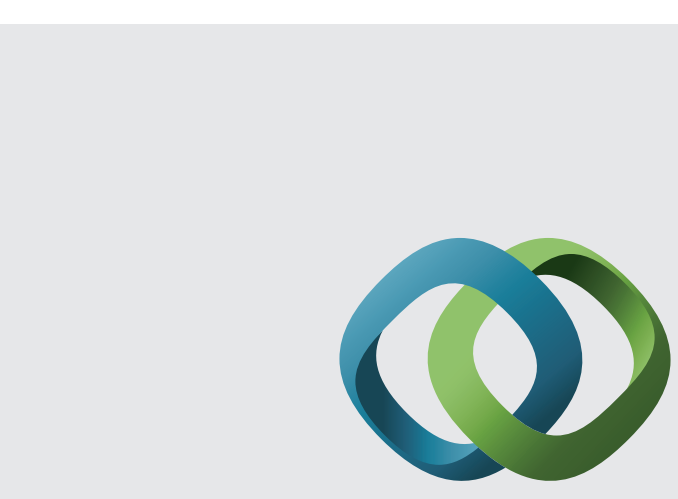

\section{Hindawi}

Submit your manuscripts at

http://www.hindawi.com
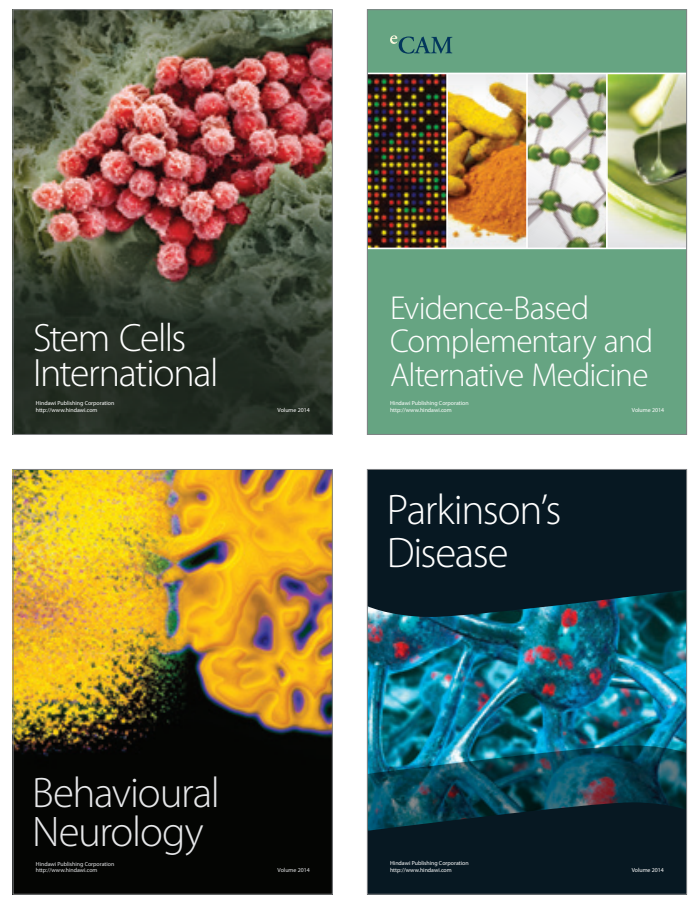
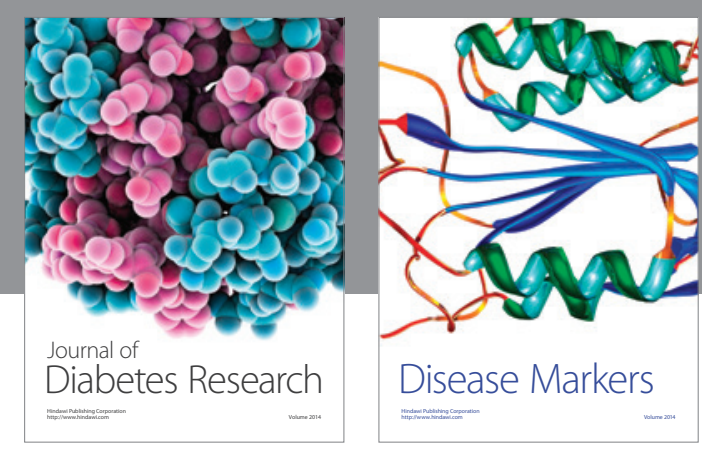

Disease Markers
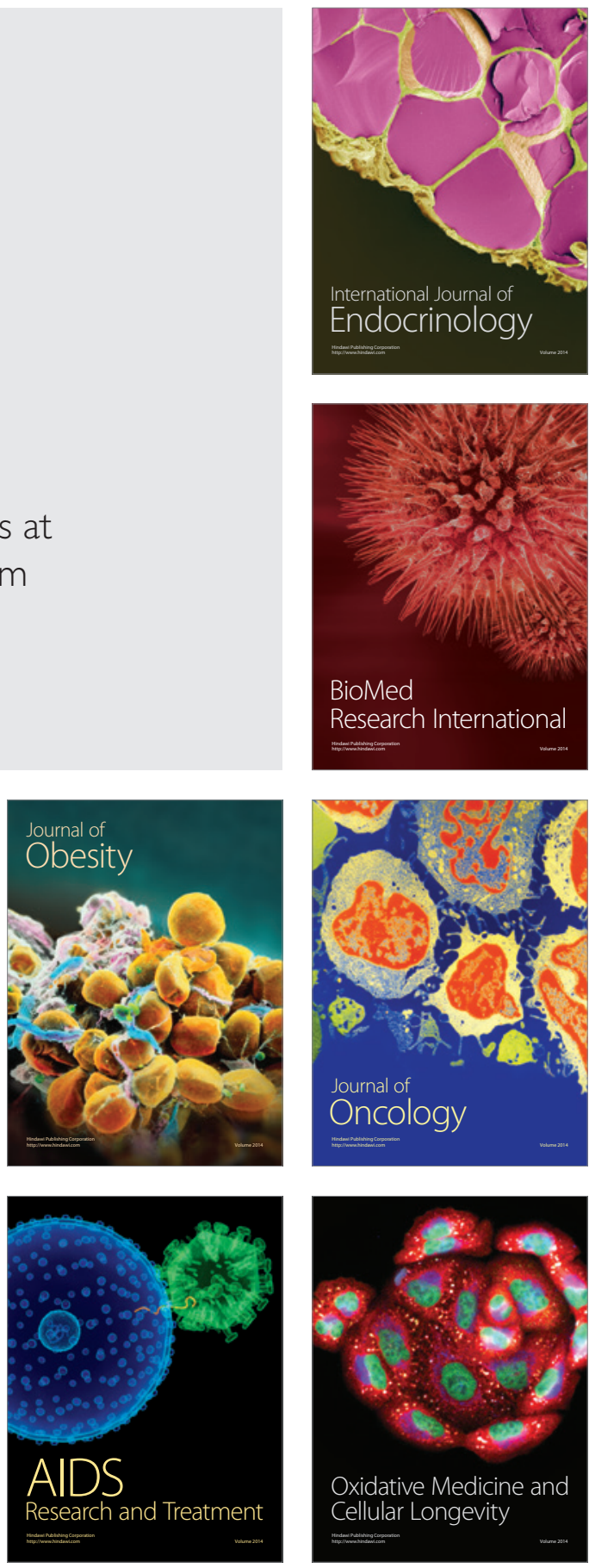